\title{
An integrated malaria control program with community participation on the Pacific Coast of Colombia
}

\author{
Un programa de control integrado de malaria \\ con participación comunitaria en la Costa Pacífica \\ de Colombia
}

William Rojas 1

Sonia Botero 2

Hector Ivan Garcia 3

\footnotetext{
${ }^{1}$ Corporación para Investigaciones Biológicas. Carrera $72 A$ No. $78 B-141$. A.A.7378, Medellín, Colombia. cib@epm.net.co

2 Centro Internacional de Educación y Desarrollo Humano (CINDE). San José, Kilómetro 1 Sabaneta, Antioquia, Colombia.

3 Departamento de Medicina Preventiva y Salud Pública Facultad de Medicina, Universidad de Antioquia. Calle 67 no 53-108, Medellín, Colombia.
}

\begin{abstract}
The study focuses on integrated malaria control in 23 communities on the Pacific Coast of Colombia, with several elements of an ecosystem approach to human health, including malaria-related sociopolitical, ecological, and economic factors. The program fostered community participation. The program presented here had 2 components: implementation and research. The first was conducted in 23 communities, 21 of which lacked adequate health services in terms of education, community participation, prompt diagnosis and complete treatment, and vector control. Research focused on specific vector control measures and the current national health services decentralization process. The project: 1) created a malaria prevention culture in the community; 2) avoided deaths from malaria (no fatal cases in the 3-year period, compared to 5-8 deaths a year previously); 3) avoided cases of cerebral malaria (no cases, as compared to 90-110 per year previously); 4) reduced malaria incidence by 45.36\%; 5) decreased length of sick leave from 7.52 to 3.7 days; 6) established a permanent network of microscope technicians and 2-way radio communications; 7) integrated work by local, regional, and outside institutions; 8) demonstrated efficacy of insecticide-impregnated bednets to reduce malaria transmission.
\end{abstract}

Key words Malaria; Insect Vectors; Community Participation; Prevention and Control; Public Health

Resumen Se presentan los resultados de un programa de Control Integrado de Malaria con participación comunitaria en 23 comunidades de la parte norte de la Costa Pacífica de Colombia, en 21 de las cuales la atención médica es prestada únicamente por una auxiliar de enfermería. Participaron 11.468 habitantes bajo la coordinación de la Corporación para Investigaciones Biológicas (CIB), del Centro Internacional de Educación y Desarrollo Humano (CINDE) y del Instituto Colombiano de Medicina Tropical (ICMT). Se emplearon 3 estrategias: educación, diagnóstico oportuno y tratamiento adecuado y control de vectores. Los resultados fueron muy satisfactorios. La incidencia disminuyó en un 45,36\%. No hubo muertes por malaria, (antes del programa se presentaban de 5 a 8 casos por año). No hubo un solo caso de malaria cerebral en los 8 años del programa; con anterioridad al programa, se presentaban 90 a 110 casos al año. La duración de los episodios de malaria disminuyó de 7,52 días a 3,7 días por episodio. El beneficio económico para la comunidad superó al costo total de la inversión en el programa.

Palabras clave Malaria; Insectos Vectores; Participación Comunitaria; Prevención y Control; Salud Pública 


\section{Theoretical framework}

\section{The problem}

Malaria is almost as great a problem today as in the 1950s. The disease is caused by the interaction of three actors: the parasite (Plasmodi$u m$ ), the vector (the Anopheles mosquito), and the host (man), as well as their interaction with both the environment and social surroundings. In our judgment, most programs have failed to control the disease because they have focused on fighting the parasite and vector while largely ignoring the role of the host, the only one who, if educated, can intervene to change the situation.

\section{Malaria in the world}

Reactivation of malaria in the world's tropical zones is a well-documented fact and one of the principal public health problems in some 100 countries. Malaria is currently the second most important infectious disease next to tuberculosis, and constitutes a serious problem for the socioeconomic development of many tropical countries (Schapira, 1997). It interferes with industrial and agricultural development, since it decreases the work potential of infected individuals and hinders food production, which in turn has a negative impact on nutrition.

One-third of the world's population live in areas at risk of malaria. Every year some 300 to 500 million people are infected with malaria, of whom 1.5 to 2.7 million die from the disease. Every 12 seconds a person dies from malaria, with children representing a high proportion of the casualties (Butler, 1997).

\section{Malaria in Colombia}

Risk of malaria transmission exists in $90 \%$ of Colombia's territory. In 1956 malaria was the greatest cause of morbidity and seventh greatest cause of mortality in the country. Thanks to the Malaria Eradication Campaign, by 1959 the number of cases had been reduced from 62,750 to 4,172 . However, a resurgence of the disease allowed the incidence to slowly increase to the point that 187,082 cases were reported in 1995. There is also extensive under-reporting due to various factors, such as social and economic turmoil and low coverage of diagnostic services, among others. The actual number of cases is estimated at some 500,000 per year (MSC, 1996).

\section{Malaria on the Chocó Pacific Coast}

The population on the northern Pacific Coast, in the Department (sub-regional geographic unit, equivalent of a State) of Chocó, live in communities ranging from 100 to 2,000 inhabitants each, where malaria is endemic.

Cases involving Plasmodium falciparum and Plasmodium vivax have occurred. It is possible that $P$. falciparum is predominant given the racial characteristics of the population, predominantly of African descent. Absence of the Duffy antigen in their red blood cells makes them naturally immune to infection by P. vivax (Miller et al., 1976; Montoya et al., 1994).

The Julio Figueroa Villa Hospital of Bahía Solano provides services to El Valle, Huina, Mecana, Huaca, Playita de Potes, Nabugá, Cupica, Brazo, Poza Mansa, Boroboro, and the municipal seat of Bahía Solano. The hospital has adequate information on "Principal Causes of Morbidity in Out-Patient Consultations by Age Group”, corresponding to 1984-1988, during which period malaria was the main cause for consultation, with $850,984,979,1,401$, and 1,507 cases respectively. This means that an average of 1,007 cases were consulted annually for a population of 5,849 (Table 1).

In drafting the population survey that served as the basis for Phase II, each household was questioned about deaths due to malaria during the previous year. Four deaths were reported in the town of Nuquí and six in Bahía Solano, for a total of ten in 1992, with 133 hospital admissions.

In the absence of diagnostic and treatment facilities in an endemic malaria area like the Chocó Pacific Coast, each inhabitant might have suffered a malaria episode per year, as occurred in Cupica in 1987 and 1988 and in Arusi from 1989 to 1991. At any given moment, up to $20.6 \%$ of school-age children and $11.5 \%$ of the general population can present some degree of infection by Plasmodium. Some $1.3 \%$ of the population was hospitalized for malaria, and $0.1 \%$ died from the same cause.

\section{Malaria control}

\section{The World Health Organization's Malaria Eradication Program}

Two important advances in the mid-20th century led the medical community to believe that the disease could be eradicated. In 1930, Anopheles gambiae, the most effective vector for the disease in Africa, arrived in Brazil. By 


\begin{tabular}{|c|c|c|c|c|c|c|c|c|c|c|c|}
\hline Rank & 1984 & 1985 & 1986 & 1987 & 1988 & 1992 & 1993 & 1994 & 1995 & 1996 & 1997 \\
\hline 1 & $\begin{array}{l}\text { Malaria } \\
14.9^{\star} \\
850^{\star \star}\end{array}$ & $\begin{array}{l}\text { Malaria } \\
14.8 \\
984\end{array}$ & $\begin{array}{l}\text { Malaria } \\
10.6 \\
979\end{array}$ & $\begin{array}{l}\text { Malaria } \\
19.9 \\
1,401\end{array}$ & $\begin{array}{l}\text { Malaria } \\
18.8 \\
1,507\end{array}$ & $\begin{array}{l}\text { Malaria } \\
15 \\
1,160\end{array}$ & $\begin{array}{l}\text { ARI } \\
10.2\end{array}$ & $\begin{array}{l}\text { Wounds } \\
4.7\end{array}$ & $\begin{array}{l}\text { ARI } \\
7.9\end{array}$ & $\begin{array}{l}\text { Parasitosis } \\
4.7\end{array}$ & $\begin{array}{l}\text { ADD } \\
4.5\end{array}$ \\
\hline 2 & ARI & UTI & ARI & ARI & ARI & ARI & $\begin{array}{l}\text { Malaria } \\
7.7 \\
546\end{array}$ & $\begin{array}{l}\text { Malaria } \\
4.3 \\
315\end{array}$ & $A D D$ & ARI & ARI \\
\hline 3 & Pregnan & Parasit. & Caries & Pregnan. & Caries & Parasit. & Wounds & ARI & Parasit. & $A D D$ & UTI \\
\hline 4 & Parasit. & $A D D$ & UTI & Parasit. & Wounds & Wounds & Parasit. & $A D D$ & Wounds & HBP & $\mathrm{HBP}$ \\
\hline 5 & Otitis & Pioderm & Parasit. & ADD & Parasit. & UTI & UTI & Otitis & $\begin{array}{l}\text { Malaria } \\
2.8 \\
211\end{array}$ & UTI & Parasit. \\
\hline 6 & ADD & $\mathrm{HBP}$ & Pioderm & Asthma & UTI & Dermat. & ADD & Asthma & $\mathrm{HBP}$ & $\begin{array}{l}\text { Malaria } \\
1.3 \\
107\end{array}$ & LBP \\
\hline 7 & Scabies & Scabies & Root canal & UTI & $A D D$ & Anemia & Anemia & $\mathrm{HBP}$ & Pioderm & LBP & Otitis \\
\hline 8 & UTI & Asthma & Gengivit & Pioderm & Root canal & ADD & $\mathrm{HBP}$ & LBP & Otitis & Otitis & Piodermit \\
\hline 9 & Asthma & Pneum. & Wounds & Otitis & Pioderm & HBP & Dermatit & Abscess & LBP & Piodermit & $\begin{array}{c}\text { Malaria } \\
0.9 \\
75\end{array}$ \\
\hline 10 & Other & Other & ADD & Other & Pneum. & Asthma & Asthma & Parasitosis & Asthma & Asthma & Other \\
\hline
\end{tabular}

* Rate, ** Cases for year.

ARI - acute respiratory infection; ADD - acute diarrheic disease; UTI - urinary tract infection; HBP - high blood pressure; LBP - lumbar back pain.

1938 it had invaded an extensive area in the northeastern region of Brazil. Fortunately, Sopper (1943) was able to eradicate it using Paris green as a larvicide. Shortly thereafter, in 1945 , Müller developed DDT, which was labeled the ideal insecticide due to both its ability to kill mosquitoes and its residual effect (Harrison, 1978). However, several species of mosquitoes developed resistance to DDT. On the other hand, because DDT is not biodegradable, it has created environmental problems that have led to its use being prohibited in most countries of the world.

In the 1950s, two effective drugs, chloroquine and primaquine, were developed to control the different species of the parasite. Unfortunately, the parasite created resistance to these two drugs as well, and development of new anti-malarial drugs has not progressed as rapidly as hoped.

In analyzing the limited results of the eradication campaign begun in 1954, the World Health Organization (WHO) proposed control alternatives with emphasis on primary medical are (WHO, 1986) and adequate vector control. Our group believes that these components should be integrated, while also including education and community participation in the search for continuity in control programs, thus creating a program whose main thrust is man himself.

\section{The use of bed nets impregnated}

\section{with insecticides}

\section{- Background}

One way to decrease contact between the vector and human beings is the use of bed nets. In many communities located close to lakes, ponds, rivers, and other bodies of water, the annoyance caused by repeated bites from all kinds of mosquitoes, especially those of genus Culex, has led to the use of bed nets by inhabitants. These undoubtedly help protect against the annoyance of mosquitoes and have partially decreased malaria incidence, according to several investigators: Arredondo-Jimenez et al. (1997) in Mexico, Magbity et al. (1997) in Sierra Leone, and Lin et al. (1986) in China. However, after careful studies, Snow et al. (1986) concluded that with 
regard to malaria transmission, use of bed nets has failed to show encouraging results, since the incidence with and without their use is similar.

There is sufficient evidence based on field work to conclude that impregnating bed nets with insecticides increases their efficiency in preventing mosquito bites and thus in controlling vector-borne diseases such as malaria.

\section{Use of pyrethroids in malaria-control campaigns}

In 1988, based on work carried out in the Gambia, Snow reported that the use of TIP decreases the rate of mosquito bites by $90 \%$ and reduces incidence of clinical malaria by $72 \%$. Additionally, Curtis (1991) found that insecticideimpregnated bed nets, if employed by a large percentage of the inhabitants in a community, could also reduce mosquito density.

According to Chinese investigators, impregnating bed nets with DDT, which is feasible, is more expensive than using deltamethrine and provides less favorable results (Curtis, 1992).

\section{Biological vector control}

In 1983, the Centro Internacional de Educación y Desarrollo Humano (CINDE) and the Corporación para Investigaciones Biológicas (CIB) initiated the evaluation of a nematode, Romanomermis culicivorax, in controlling Anopheles in the community of El Valle, in the municipality of Bahía Solano. Control operated out of the county seat of Nuquí (Rojas et al., 1987).

Before the initial study, malaria prevalence was $21.7 \%$ in El Valle and $10.0 \%$ in Nuquí. After planting 44 million Romanomermis eggs in all the breeding spots located within a 7 -kilometer radius around the urban area, a progressive decrease in malaria prevalence was obtained, with no other intervention. The level was measured every six months and a decrease was observed until reaching $0.8 \%$ in El Valle, while there was no significant change in the control population. The Anopheles larvae slowly diminished and disappeared 15 months after applying Romanomermis. Unfortunately, they reappeared three months later, at month 18 , due to infection of the nematode by a nematophagous fungus. That is, a natural biological control of the nematode arose in the same area.

From 1988 to 1992, CIB conducted a study financed by the WHO to investigate potential pathogens and predators of mosquito larvae in different areas of Colombia. Of the 280 entomo-pathogenic bacteria found, B. thuringiensis, sub-species Medellin, is molecularly char- acterized as being very promising for controlling malaria vectors, Orduz et al. (1992). There are numerous relevant studies on biological vector control, but none has succeeded in standardizing an efficient and economic method.

\section{Malaria control in Colombia}

In 1954 Colombia joined the WHO-sponsored world campaign to eradicate malaria and was able to decrease the incidence of 62,750 cases reported before the campaign to 4,172 in 1959 (Suárez, 1991). Such results are comparable to those obtained in other countries.

However, the program's high costs, problems of social unrest, and the development of parasite resistance to chloroquine and vector resistance to DDT led to a progressive deterioration in the program.

In the early 1990s, a health services decentralization process was launched in the country. In 1992, the National Government decided to dismantle the Malaria Eradication Service (SEM) by decentralizing it and transferring responsibility to the Departments and municipalities for organizing and supervising health care, including vector-borne diseases such as malaria, dengue, yellow fever, and leishmaniasis.

Complete dismantling of the SEM was finally achieved in 1996 and unfortunately caused some problems in most of the Departments, where the Regional Health Services (SSS) lacked the adequate infrastructure and know-how to conduct a malaria control program.

In some Departments the Governors, who were accustomed to malaria control being conducted by the Ministry of Health, delayed or have still not taken charge of this work.

Malaria control results under the decentralization process are hardly satisfactory (OPS, 1997). Similar results have appeared in South America as a whole (Roberts et al., 1997).

\section{The Integrated Malaria Control Program}

\section{Background}

In 1985, through a volunteer program for primary medical care led by the Colombian Air Patrol, several CIB physicians and bacteriologists participated in periodic visits to a remote community, Cupica, on the northern Pacific Colombian coast. After three visits and during a meeting with the community, the Cupica inhabitants pleaded for the CIB program representatives to "do something to control malaria, which is killing us all." 
CIB had not previously participated in field or malaria control programs, except for some work in biological vector control. The villagers' plea was taken as a challenge. CIB members began a review of the malaria control bibliography and consultations with entomologists, epidemiologists, community workers, and educators. Special attention was given to analyzing the reasons for the failure of the socalled "Malaria Eradication and Control Program Campaign" launched by the World Health Organization in 1952.

Program strategies were based on the experience acquired during the first phase of the “Community Malaria Control” program, carried out in four communities in the same region and consisting of education, training, inter-institutional coordination, technical assistance, and evaluation. All these measures were applied jointly, producing a $90 \%$ reduction in malaria transmission, and no cases of cerebral malaria or deaths from malaria were found during the three years that the program lasted. Additionally, the length of medical sick leaves attributable to the disease was decreased by $50 \%$ (Figure 1).

\section{Program area}

The region is one of the poorest and most backward in Colombia. The heavy rainfall, with one of the world's highest pluviometric indices $(6,000-8,000 \mathrm{~mm} /$ year $)$, leads to the formation of pools and ponds close to houses, in which Anopheles albimanus, the principal malaria vector, breeds. Characteristics of the tropical rain forest surrounding the communities facilitates proliferation of bromelias in the trees where water accumulates, serving as aerial breeding sites for Anopheles neivai, the second most important vector in the area.

These ecological characteristics had not changed during the ten years prior to launching the program. The El Niño phenomenon occurs cyclically, every four to five years. The phenomenon is responsible for the well-known peaks in malaria transmission that have been detected epidemiologically every four to five years for the last 30 years (Poveda et al., 1999). During El Niño, there is an appreciable increase in temperature (up to ${ }^{\circ} \mathrm{C}$ ) and a drop in rainfall. The former shortens the Plasmodium parasite's life cycle in the mosquito, making it a better vector. The decreased rainfall in turn causes the ponds serving as mosquito breeding grounds to become more productive. This occurs because the larva washout effect due to the constant rainfall is interrupted, exactly the opposite of what is observed in most endemic malaria areas, where the lack of (or decrease in) rainfall reduces the number and/or size of mosquito breeding grounds.

Housing characteristics in the area allow for the free circulation of vectors. Due to the high temperatures, houses have been built with gaps in the walls to allow air to circulate. The poor-

Figure 1

Incidence of malaria in Cupica.

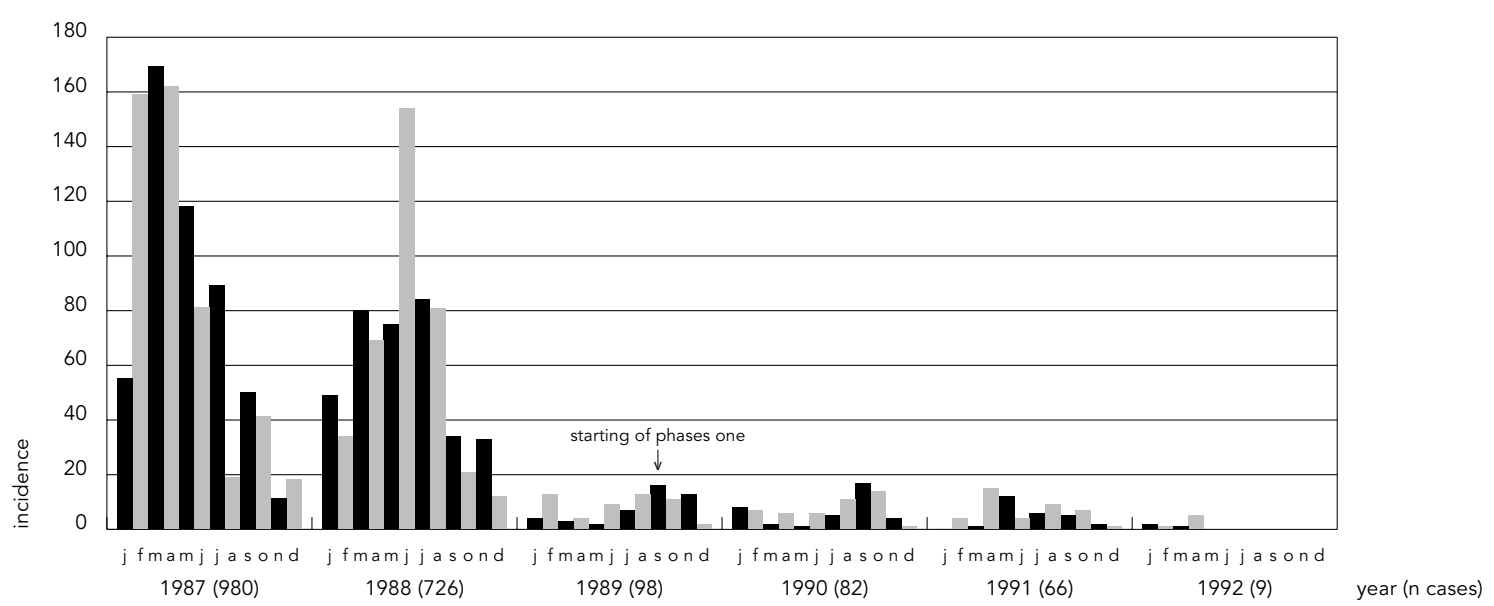


quality housing has not undergone any modifications, given the low prevailing socioeconomic standards.

There is no direct effect of central government actions on socioeconomic conditions in these communities because they are so far removed and lack adequate communications. Communication among the communities themselves is only possible by sea, and this is expensive and discontinuous. Implementation of radio communications constitutes an important step forward and has rescued these communities from total isolation, due to which they had remained totally overlooked by government at both the Department and municipal levels.

\section{Objectives}

\section{- General}

Implement and evaluate an Integrated Malaria Control Program (IMCP) in 23 communities on the Chocó Pacific Coast, with community participation, supporting the health services decentralization process and simultaneously investigating the potentially favorable effects of specific measures to control malaria vectors.

\section{- Specific}

a) Evaluate the impact IMCP has on malaria morbidity and mortality.

b) Explain the changes in education, organization, community participation, leadership, management, and decentralization achieved through the program's implementation.

c) Strengthen the capability of local communities and institutions to plan, administer, implement, evaluate, and sustain the control program.

d) Strengthen a malaria diagnosis and treatment network in the 24 communities.

e) Apply vector control measures, such as digging ditches and removing bromelias (the breeding site for one of the vector species) from trees in urban areas.

f) Develop a communications network through two-way radios to guarantee surveillance and control of all aspects of the program.

g) Progressively transfer the program management to the local and regional communities and authorities.

\section{Population}

The population included in the IMCP, which included community participation, is located on the Gulfs of Tribugá and Cupica, on the
Colombian Pacific Coast (see map in Figure 2). There were a total of 11,468 inhabitants in the coastal areas, according to the population survey conducted by the research group in October 1995.

Administratively, the Gulfs of Tribugá and Cupica come under the jurisdiction of the municipalities of Nuquí and Bahía Solano, respectively. From South to North, the towns or villages located on the Tribugá Gulf coast are Arusí, Partadó, Termales, Joví, Coquí, Panguí, Nuquí, Tribugá, and Jurubidá. In the Cupica Gulf the towns or villages are El Valle, Huina, Bahía Solano, Mecana, Huaca, Playita de Potes, Nabugá, and Cupica.

At the request of several of their leaders, the indigenous communities of El Brazo, Boroboro, and Poza Mansa in Bahía Solano and Panguí Arriba, Nuquí Arriba, and Chorí in Nuquí were included in the study.

There were no major migratory processes occurring at the time of the intervention. The communities were thus relatively stable with regard to number of inhabitants. There is a relatively low illiteracy rate, $14.5 \%$, facilitating malaria control education.

\section{Coordination}

The project was planned, implemented, and evaluated with the participation of all the various stakeholders. Figure 3 shows the interactions in the planning and evaluation stages.

A Central Coordinating Committee (CCC) was set up to take charge of the general project coordination. The following institutions were represented: CIB, CINDE, ICMT (Instituto Colombiano de Medicina Tropical), PROMESA (Programa de Mejoramiento, Salud y Ambiente), SSSCH (the Chocó Regional Health Service), and the mayors of Nuquí and Bahía Solano, the two municipalities involved in the project. The CCC maintained regular meetings twice a year. Its specific role was to monitor the entire project, guaranteeing it compliance with the research plan and introducing any necessary changes.

\section{Program components}

Education, community participation, and decentralization processes were implemented. The information requested was transferred daily by two-way radio and incorporated into a data base in the Biological Investigation Corporation (CIB) laboratory. A feedback system was established to assure that the information allowed for corrections to be made during the course of the program. 


\section{- Education}

This process had the following components: social management by the community, community organization and participation, malaria control education, and decentralization of the malaria-control program. The process was implemented on three levels: (a) with the leaders of each community; (b) with municipal-level organizations; and (c) with the Department of El Chocó Regional Health Service.

The methodology was based on the "learning-by-doing" theoretical/practical principle. The basis of the process was training and work at the local level, including activities with teachers and schoolchildren, local workshops, and coordination of activities with local institutions, etc.

\section{- Strengthening the diagnosis and treatment mechanism}

Communities ranging from 200 to 1,000 inhabitants were supplied with two part-time microscope technicians, a microscope, and all the facilities needed for rapid diagnosis and adequate treatment.

Permanent control of the process was conducted through solar energy-operated radios installed in each of the communities. All the positive smears were referred to the CIB central laboratory for confirmation and quality control. A retraining process was designed for microscope technicians who displayed limitations in their diagnostic skills.

\section{- Vector control}

Data were collected for planimetric mapping of the communities, together with the population survey. All buildings, some geographic landmarks, and land and aerial mosquito breeding sites were identified on these maps. The data on which the profiles were constructed are registered in the field notebooks filed in the CIB.

\section{Results}

\section{Education, participation,} and community management

\section{- Level of knowledge}

At the beginning of the evaluation we observed that the program participants already had a high degree of knowledge, acquired during the previous study. The educational process was
Figure 2

Communities included in the study. Pacific Coast of Colombia.

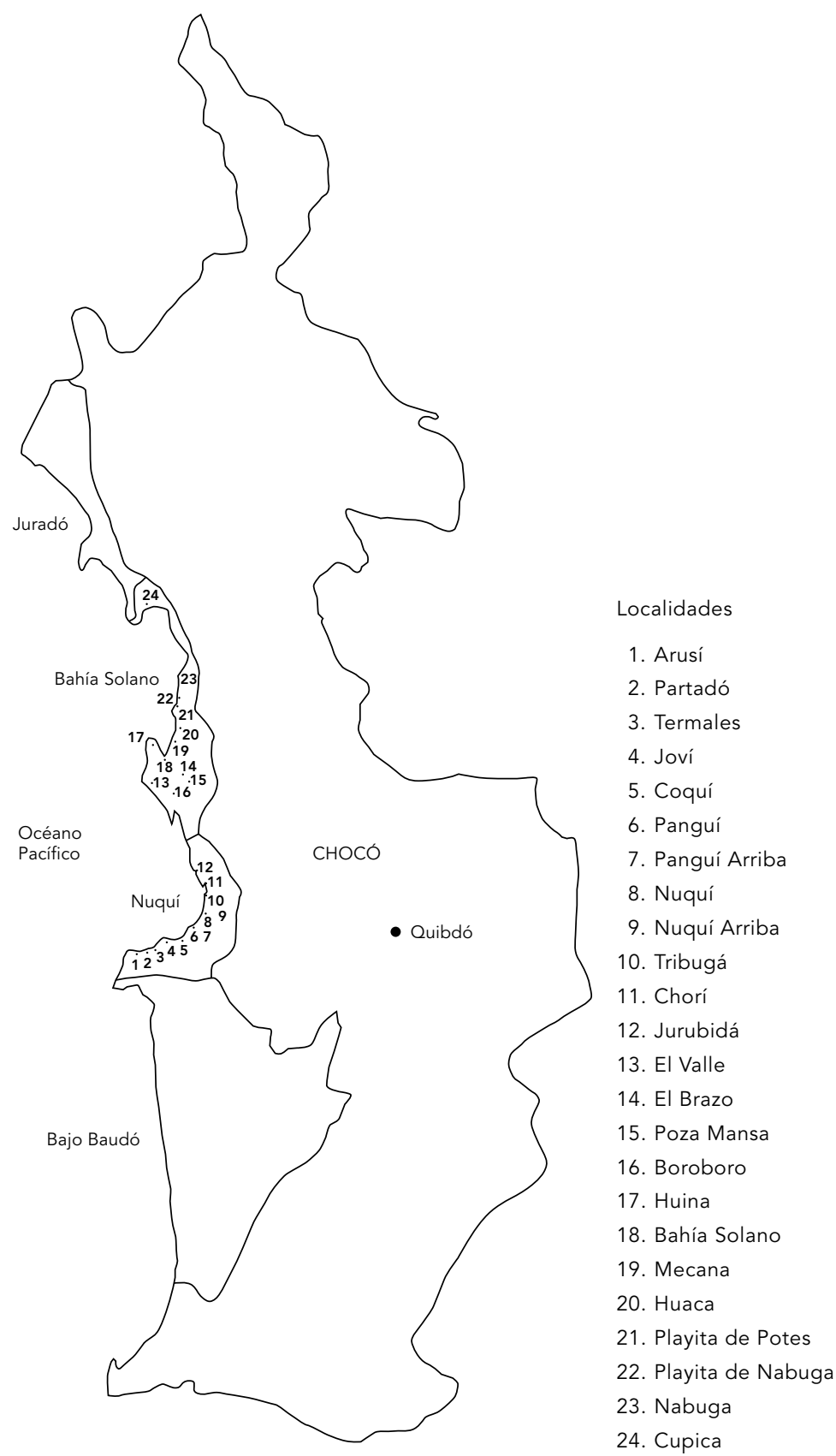


Figure 3

Planning and evaluation of deliberate

and participatory activities and spaces.

Level of participation

Activity

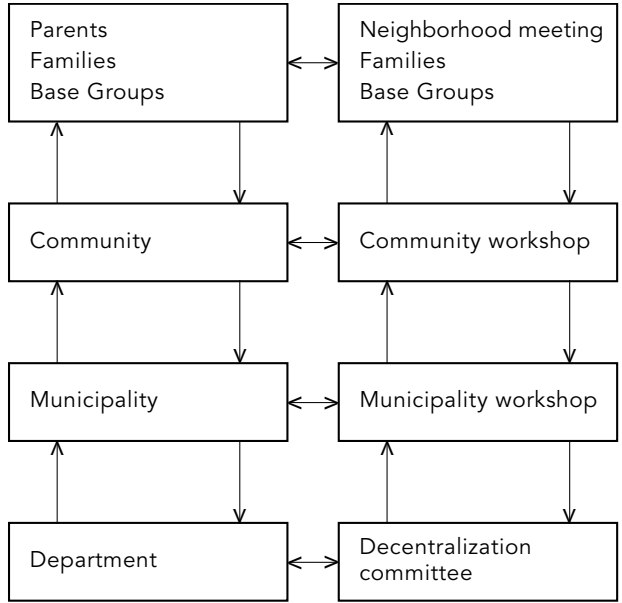

constantly strengthened through local workshops, creating a dialogue involving facts learned throughout this period, with the result that the educational process and knowledge were maintained, thus achieving stability in the entire area and what might be termed a uniform level of knowledge.

\section{- Organization}

Initially there already existed a community organization, PROMESA, that led activities in Bahía Solano and Nuquí and formed an important pillar for sustaining the process.

At the local level, the microscope technicians exercised a sustained leadership in their respective communities throughout the study.

The organization permeating the program began to generate other organizations and groups. Malaria committees were formed in the communities where they did not exist before. Work in these committees was interrupted at some stages, and some committees underwent attrition, but others remained active throughout the study, as recorded in the workshop proceedings.

Nevertheless, throughout the process we saw institutions such as mayors' offices and local institutions taking a more active role in the municipal workshops, in which decision-making was conducted jointly with the community.

\section{Prompt diagnosis and adequate treatment}

\section{- Microscope technicians}

49 persons were trained as microscope technicians, 31 of whom were young people selected by the leaders of their respective communities. The other 18 were nursing aids with no previous training in microscopic diagnosis. There were an additional eight microscope technicians in Cupica, Bahía Solano.

Following refresher courses, 37 microscope technicians obtained a kappa index of 0.8 or better in quality control.

\section{- Supervisors}

The six best microscope technicians, three from each municipality, were selected to act as such and supervise the work of the others in their municipalities. Five of them reached a kappa index of 0.9 or better in the last 12 months.

\section{- Diagnostic network}

Each community was provided with a microscope and material and equipment for diagnosis and treatment.

\section{- Communications network}

Two-way radios with electricity supplied by solar cells were installed permanently in 18 of the 23 communities. The only two places where radios were not installed were Huina and Mecana, both close to Bahia Solano. The SSSCH, which had short-range radio facilities in its office, offered to install radios in each of the communities, but failed to make good on this offer.

\section{Malaria incidence in the municipalities}

Over the course of the 36 months, in the communities of Nuquí and Bahía Solano, 32,750 smears were taken, 15,985 of which were for diagnosis and 205 for control. Of the slides for diagnosis, 26,639 were negative. Positive smears included 3,315 for P. vivax, 3,036 for P. falciparum, and 38 mixed.

During the 12 months prior to implementation of the Integrated Control Program, there were 1,643 malaria cases in Bahía Solano and 3,024 in Nuquí. Thus, incidence decreased from 4,667 to 2,117 a year (a drop of $45.36 \%$ ).

With respect to cerebral malaria, the only data were provided verbally by the physician in Nuquí, who had been working there for two years and reported having treated "more than 
60 cases of cerebral malaria during the period". During the three years of the program there was not a single autochthonous case of cerebral malaria in the 24 target communities.

No deaths from malaria were reported during the program's 36 months. Since there might have been incomplete reporting owing to the conditions in the area, an independent infectologist was sent to investigate village-by-village whether there had been any deaths that could be attributed to malaria, using the "autopsy by interrogation" methodology recommended by the WHO. No death attributable to malaria was detected. Likewise, in each workshop there was insistent questioning concerning events in the previous six months, and clearly there were no deaths caused by malaria.

\section{Vector control}

To study the vectors, 144 land and 134 aerial breeding sites were sampled in 20 localities. Of the land breeding sites tested, 76 (52.8\%) were positive for Anopheles larvae, with six species found (Anopheles albimanus, Anopheles neomaculipalpus, Anopheles strodei, Anopheles aquasalis, Anopheles triannulatus, and Anopheles neivai). Of the above-ground breeding sites, $70(52.2 \%)$ tested positive for two species ( $A n$. neivai and An. albimanus).

The majority of the Anopheles specimens found were An. albimanus, present in 35 breeding sites, and An. neomaculipalpus, in 31. The other four species (An. strodei, An. aquasalis, An. triannulatus, and An. neivai) were found in only six breeding sites.

\section{Breeding ground drainage and filling}

Once the breeding grounds had been defined as susceptible to drainage, each community was supplied with the necessary tools to dig ditches towards lower terrain or out into the sea. The ditches were dug according to maps and plans drafted by a topographer, and members of the respective communities were in charge of digging them.

In meetings with community leaders, mingas (community work crews) were organized to dig the drainage ditches. A total of 13,500 meters of ditches were dug, and 35 medium-sized mosquito breeding grounds were filled. For logistic reasons, no measurements of the population densities were taken, but these measures undoubtedly have a permanent and important effect.

\section{Removal of bromelias}

Having identified the aerial breeding sites (bromelias on tree trunks), community activities to coordinate their removal were carried out. Mingas or community work crews were formed to maintain the ditches and remove the bromelias regularly.

\section{Discussion}

The malaria control strategy has evolved in the last decade and the three basic recommendations have been incorporated into the program. - Integrate primary health care with malaria management, according to WHO guidelines since 1986, in agreement with Siem Tjam (1986) and Beales (1986).

- Promote community participation in malaria control campaigns. Health professionals need to modify their attitudes and change from being principal actors to associates in a process. Service (1993) has performed an excellent review of this issue, and one of his articles mentions that the project described herein should be monitored for continuity. We also make a point of this recommendation.

- Ensure that malaria control is integrated, which is what Liu et al. (1986) and Bryce et al. (1994) have done in China and Africa, respectively.

This Integrated Malaria Control Project has proven that education and collaboration with the community are important components in the struggle against malaria.

Education, especially focusing on schoolage children, helped clear ideas take root in the community concerning what malaria is, how it manifests itself, what produces it, how it is transmitted, and how it can be diagnosed in a timely manner and treated adequately. Likewise, the community grasped the basic concepts of the hazards of self-medication and incomplete treatment. Community education remained virtually constant over the last three years.

\section{Conclusions}

With simple, accessible measures, applicable in any endemic malaria region, it is possible to adequately control the disease. An Integrated Malaria Control Program (IMCP) was proven to be effective in the field, in 23 communities on the Chocó Pacific Coast of Colombia.

An important component of the IMCP was that it included man, the only one of the three 
actors in the malaria drama who can be educated. The educational program was carried out through courses, community meetings, and workshops in the communities and municipalities in which leaders and authorities participated.

As in other existing malaria control programs in Colombia and the rest of the world, the parasite and vector were kept in mind, implementing measures for the immediate diagnosis and timely, complete treatment, in addition to measures to decrease vector density.

Through the IMCP, deaths were avoided, the incidence of cerebral malaria (the most serious complication) was reduced by $46 \%$, and average sick leave due to malaria decreased from 7.6 to 3.6 days.

Fewer cases and the absence of complications and hospitalizations meant enormous economic savings for the communities.

We believe that the program should be implemented in other endemic areas of the country and continent, with the necessary adaptations for each region.

\section{Acknowledgments}

We wish to thank the CIID, Colombian Ministry of Health, National Planning Department, mayors' offices of Bahía Solano and Nuquí, and Chocó Sectional Health Service for the cooperation and financing of the program.
The success and continuity of an integrated control program for a disease such as malaria is based on the true integration of ecological, cultural, biological, administrative, and political aspects. It is essential that community leaders and health officials participate in the program's design and implementation. Therefore, they should be involved from the beginning and participate actively in the entire process. There should be no discrimination based on race, sex, religion, or age.

More emphasis could be placed on sanitary engineering measures involving more permanent control of mosquito breeding grounds through drainage or filling. This work should not be contracted out to companies that are external to the community and should be organized in such a way that the economic benefits of the activity favor the inhabitants who wish to participate. Thus, their precarious financial situation is improved somewhat and, very importantly, programs are able to assure that the community takes charge of the work to be done and commits itself to its proper maintenance and continuity.

\section{References}

ARREDONDO-JIMENEZ, J. I.; RODRIGUEZ, M. H.; LOYOLA, E. G. \& BOWN, D. N., 1997. Centro de Investigación de Paludismo, Instituto Nacional de Salud Pública, Tapachula, Chiapas, México. Medical Veterinary Entomology, 11:87-94.

BUTLER, D., 1997. Time to put malaria control on the global agenda. Nature, 386:535.

CURTIS, C. F., 1991. Control of Disease Vectors in the Community. London: Wolfe Publications.

CURTIS, C. F., 1992. Personal protection methods against vector of disease. Review of Medical and Veterinary Entomology, 80:543-553.

HARRISON, G., 1978. Mosquito, Malaria, and Man. New York: E. P. Dutton.

LIU, Y. L.; WU, K. S.; ZHANG, Y. G.; JIA, J. X.; JIANG, B. Q.; ZHANG, J. Y.; ZHOU, W. K. \& WANG, K. A., 1986. Integrated approach to malaria control emphasizing reduction of man-mosquito contact. Chinese Medical Journal, 99:879-884. 
MAGBITY, E. B.; MARBIAH, N. T. \& MAUDE, G., 1997. Medical Research Centre, Bo, Sierra Leone. Medical Veterinary Entomology, 11:79-86.

MILLER, L.; MANSON, S.; CLYDE, D. F. \& GINNISS, M., 1976. The resistance factor to $P$. vivax in blacks. The Duffy blood group genotype Fy Fy. New England Journal of Medicine, 395:302-304.

MONTOYA, F.; RESTREPO, M.; MONTOYA, A. \& ROJAS, W., 1994. Blood groups and malaria. Revista do Instituto de Medicina Tropical de São Paulo, 36:33-38.

MSC (Ministerio de Salud de Colombia), 1996. Informe sobre Malaria. Bogotá: Ministerio de Salud.

OPS (ORGANIZACION PANAMERICANA DE LA SALUD), 1997. Informe de la Evaluación del Programa de Control de la Malaria en Colombia. Medellín: OPS.

ORDUZ, S.; ROJAS, W.; CORREA, M. M.; MONTOYA, A. E. \& DE BARJAC, H., 1992. A new subspecies of Bacillus thuringiensis from Colombia, toxic to mosquito larvae. Journal of Invertebrate Pathology, 59:99-103.

POVEDA, G.; ROJAS, W.; QUIÑONES, M. L.; MESA, O. J.; VELEZ, I. D.; CHAVASSE, D.; GARCIA, H. I.; DYNER, Y.; BOUMA, M. \& COX, J., 1999. Climate and ENSO variability associated with malaria and dengue fever in Colombia. In: Proceedings of the 10th Symposium on Global Change Studies, pp. 173-176, Dallas: American Meteorological Society.
ROBERTS, D. R.; LAUGHLIN, L. L.; HSHEIH, P. \& LEGTER, L. J., 1997. DDT, global strategies, and a malaria control crisis in South America. Emerging Infectious Diseases, 3:295-302.

ROJAS, W.; NORTHUP, J.; GALLO, O.; MONTOYA, A. E.; MONTOYA, F.; RESTREPO, M.; NIMNICH, G.; ARANGO, M. \& ECHAVARRIA, M., 1987. Reduction of malaria prevalence after introduction of Romanomermis culicivorax (Mermithidae: Nematoda) in larval Anopheles habitats in Colombia. Bulletin of the World Health Organization, 65:331337.

SCHAPIRA, A., 1997. Malaria control in 1995: Constraints and opportunities. Annals of Tropical Medicine and Parasitology, 91:S85.

SNOW, R. W.; ROWMAN, K. M.; LINDSAY, S. W. \& GREENWOOD, B. M., 1986. A trial of bed nets (mosquito nets) as a malaria control strategy in a rural area of the Gambia, West Africa, Transactions of the Royal Society of Tropical Medicine and Hygiene, 82:212-219.

SOPPER, L. F. \& WILSON, D. B., 1943. Anopheles gambiae in Brasil. New York: Rockefeller Foundation.

SUAREZ, E., 1992. Evaluación de las Políticas Antimaláricas Implementadas Durante el Período 19591986 (1988). Bogotá: Plaza \& Janes.

WHO (World Health Organization), 1986. Informal Consultation on the Use of Biological Control Agents in Vector Control Programmes. WHO Document No. VBC (ECV) TDR/IC. 86.24. Geneva:WHO. 